\title{
Yartsagunbu: transforming people's livelihoods in the Western Himalaya
}

\author{
Pramod Kumar Yadav, Subhajit Saha, Ashish Kumar Mishra \\ Mohnish Kapoor, Manendra Kaneria, Manish Kaneria \\ Sabyasachi Dasgupta and Uttam Babu Shrestha
}

\begin{abstract}
Rural communities in developing countries extract provisioning ecosystem services from the natural environment to meet their subsistence needs, generate cash income and create employment opportunities. Caterpillar fungus Ophiocordyceps sinensis, known as yartsagunbu in Tibet and in the literature on this subject, is a medicinal resource extracted by the mountain communities of the Himalaya. Studies of the contribution of the fungus to local livelihoods in the Indian Himalaya are scarce. We investigated trade and harvest and analysed the contribution of caterpillar fungus to household economies in 32 villages in Dhauliganga Valley, Nanda Devi Biosphere Reserve, in the Western Himalaya. Caterpillar fungus harvesting has become an integral part of local livelihoods in the study area, and on average contributes c. $74 \%$ of household cash income. The majority of harvesters perceived that harvesting had become more difficult during 2010-2015 as a result of competition and a decline in abundance of the species. The mean annual per capita harvest declined by 54 pieces during 2011-2015. Increasing harvesting and trade, coupled with the dependency of local communities on the fungus, may result in greater extraction of the resource for shortterm economic benefits, and could eventually lead to depletion and ecological damage. Harvesting of the fungus has already created environmental, legal and social challenges, although it has become a lucrative livelihood opportunity. The ongoing decline of the fungus threatens local livelihoods. Good governance and livelihood security should be
\end{abstract}

Pramod Kumar Yadav (Corresponding author) Climate Change and Sustainable Development Division, Centre for Integration of Conservation and Developmental Accountability, Dehradun, Uttarakhand, India E-mail pramod.yadav31@gmail.com

SubHajtT SAHA Himalayan Exploration, Conservation and Livelihood Programme, Dehradun, Uttarakhand, India

Ashish Kumar Mishra Department of Environmental Science, Babasaheb Bhimrao Ambedkar University, Lucknow, Uttar Pradesh, India

MoHnish Kapoor Global Tiger Forum, New Delhi, India

ManendRa Kaneria and Manish Kaneria Entomology Division, Forest Research Institute, Dehradun, Uttarakhand, India

SABYASAChi DasGupta Department of Forestry and Natural Resources, Hemvati Nandan Bahuguna Garhwal University, Srinagar, Uttarakhand, India

UtTAM Babu SHRESTHA Institute for Agriculture and the Environment, University of Southern Queensland, Toowoomba, Queensland, Australia

Received 2 February 2018. Revision requested 12 April 2018.

Accepted 2 May 2018. First published online 18 December 2018. integrated with biodiversity conservation when devising government policies and plans for sustainable management of the caterpillar fungus.

Keywords Biosphere Reserve, caterpillar fungus, ecosystem services, Himalaya, non-timber forest products, Ophiocordyceps sinensis, yartsagunbu

\section{Introduction}

D ural communities in developing countries extract Rrovisioning ecosystem services, including food, fuel, fodder, construction materials and medicine, from forests and other natural or non-cultivated environments to fulfil their subsistence needs, generate cash income and create employment opportunities (Angelsen et al., 2014). In India, for example, trade of non-timber forest products (NTFPs) is valued at USD 2.7 billion annually, providing $55 \%$ of employment in the forestry sector and supplying $50 \%$ of the domestic earnings for approximately one-third of India's rural inhabitants (Mahapatra \& Shackleton, 2011). In the Indian Himalaya, the reliance of local communities on environmental goods and services is high because other livelihood opportunities are limited by the low productivity of the land and the remoteness of the communities (Rijal et al., 2011). Historically, rural households in the Himalayan region, including the Indian Himalaya, have collected medicinal plants from the forests and other habitats, which they trade to lowland areas for their livelihoods (Smith \& Larsen, 2003). Since the collection of caterpillar fungus Ophiocordyceps sinensis spread to the Indian Himalaya from China and Nepal, local communities have begun collecting the fungus to such an extent that it has surpassed all other medicinal species in terms of revenue (Yadav et al., 2017).

The high value and market demand for caterpillar fungus attracts a large number of harvesters to alpine meadows in China (Winkler, 2009; Woodhouse et al., 2014), Nepal (Shrestha \& Bawa, 2013) and Bhutan (Wangchuk et al., 2012). Harvesting and selling of caterpillar fungus are contributing to social and economic transformations across the Tibetan Plateau and Himalayan region (Weckerle et al., 2010; Pant et al., 2017). A similar transformation has been observed in areas of the Indian Himalaya (Sharma, 2004; Singh et al., 2010), including in the Nanda Devi Biosphere Reserve, where caterpillar fungus has been collected by the 
local people since its discovery there (Yadav et al., 2017). In Uttarakhand it was first discovered in the Askot Landscape in 1996-1997 (Garbyal et al., 2004). New areas were explored for fungus collection, and in 2005 harvesting started in Dhauliganga Valley in the Nanda Devi Biosphere Reserve (Bosak \& Kainthola, 2016). The increasing pressure on livelihoods has led to the exploration of caterpillar fungus in the Nanda Devi landscape, the economic importance of which was imparted to the local community by migrant labourers from Nepal, where harvesting and trading of the fungus has a longer history.

The rampant and unregulated harvesting of caterpillar fungus in Nepal (Shrestha \& Bawa, 2014) and intensity of collection in China (Winkler, 2009) has prompted calls for sustainable resource management, raising concerns about the persistence of the species and the conservation of the pristine alpine landscape where it occurs (Winkler, 2009; Weckerle et al., 2010; Shrestha \& Bawa, 2013). Sustainable management of NTFPs, including caterpillar fungus, requires an understanding of the social, economic, ethical, religious and political factors that either encourage resource conservation or lead to resource depletion (Secretariat of the Convention on Biological Diversity, 2001). However, the ecological, economic and social dimensions of caterpillar fungus harvesting in the Indian Himalaya are relatively unknown. Previous studies have found that over-extraction of other medicinal plants is posing a severe threat to biodiversity in India (Dash et al., 2016; Tewari et al., 2017). In this context, knowledge of the economic, social and ecological dimensions of caterpillar fungus harvesting is important for the conservation of this species, given that it is being collected extensively by a large number of local people in the mountain regions of India.

Our research questions are based on the previous findings that market price influences the volume of resource extraction and leads to resource depletion (Secretariat of the Convention on Biological Diversity, 2001), and on the importance of local perceptions for sustainable resource management (Silori, 2007; Shrestha \& Bawa, 2014). The study was conducted in 32 villages in the Nanda Devi Biosphere Reserve, and was guided by three research questions: (1) What are the trends in prices for buying and selling caterpillar fungus in the study area? (2) What is the contribution of caterpillar fungus to total household cash income? (3) How do local harvesters perceive challenges regarding the collection and abundance of caterpillar fungus?

\section{Caterpillar fungus (yartsagunbu)}

The caterpillar fungus (Plate 1) is an endoparasitic complex formed by a combination of a dead caterpillar and a fungus. The fungal part of the complex belongs to the family Ophiocordycipitaceae and is a parasitic fungus.
Ophiocordyceps sinensis is a heavily traded species with high market value. The fungal spore infects the host caterpillars of ghost moths of the order Hepialidae (class Lepidoptera), grows inside the body of the host and produces a fruiting body (stroma) that emerges from the head of the larva and eventually kills it through paralysis and mummification (Winkler, 2009). As the insect's larva is the sole source of food for the fungus, the size of its stroma depends on the size of the host caterpillar (Negi et al., 2014). Caterpillar fungus has been used for various therapeutic purposes in traditional Chinese and Tibetan medicines for centuries (Shrestha et al., 2010), to strengthen lungs and kidneys, increase energy and vitality, stop haemorrhage, and decrease phlegm (Holliday \& Cleaver, 2008). Studies have shown multiple pharmacological effects of the fungus, including anti-aging (Yalin et al., 2005), anti-oxidation (Dong \& Yao, 2008) and anti-tumour activities (Ji et al., 2009; Wang \& Yao, 2011). It is also widely traded as an aphrodisiac and a powerful tonic under the name Himalayan Viagra (Winkler, 2009).

Caterpillar fungus is endemic to the Tibetan Plateau and adjoining high-altitude areas of the Himalaya, and is known locally as kirajari in India, yarsa guenbub in Bhutan (Sharma, 2004; Yadav et al., 2017), yartsagunbu in Tibet (Winkler, 2009) and yarsagumba in Nepal (Shrestha \& Bawa, 2013), and is widely referred to as yartsagunbu in the literature on this subject. The natural occurrence of caterpillar fungus is confined to the alpine and subalpine pastures of the Himalayan Mountains of Bhutan, India, Nepal, and the Qinghai-Tibetan Plateau, at 3,500-5,000 m elevation (Sharma, 2004). In India it has been recorded in alpine meadows of some protected areas, including Kanchendzonga Biosphere Reserve in Sikkim, Dehan-Debang Biosphere Reserve in Arunachal Pradesh, and Nanda Devi Biosphere Reserve and Askot Wildlife Sanctuary in Uttarakhand, among many other possible places in the Indian Himalayan region (Sharma, 2004; Singh et al., 2010; Yadav et al., 2016). In the Nanda Devi Biosphere Reserve, caterpillar fungus occurs in alpine pastures of the Dhauliganga, Gori, Mandakini, Pindar and Rishi Ganga valleys.

\section{Study area}

This study was conducted in the Nanda Devi Biosphere Reserve, in the Garhwal and Kumaon regions of Uttarakhand state in the Western Himalaya (Fig. 1). The Biosphere Reserve has rich biological and cultural diversity as well as historical significance, and was designated a UNESCO World Heritage Site in 1992 (Silori, 2007). High mountain peaks, including Nanda Devi (the highest peak entirely within India), and deep river gorges, including Rishi Ganga gorge (one of the deepest in the world), are the prominent natural features of the landscape. The Biosphere Reserve comprises two central core zones $\left(625 \mathrm{~km}^{2}\right)$ surrounded by a buffer zone $\left(1,612 \mathrm{~km}^{2}\right)$. The core zones, 


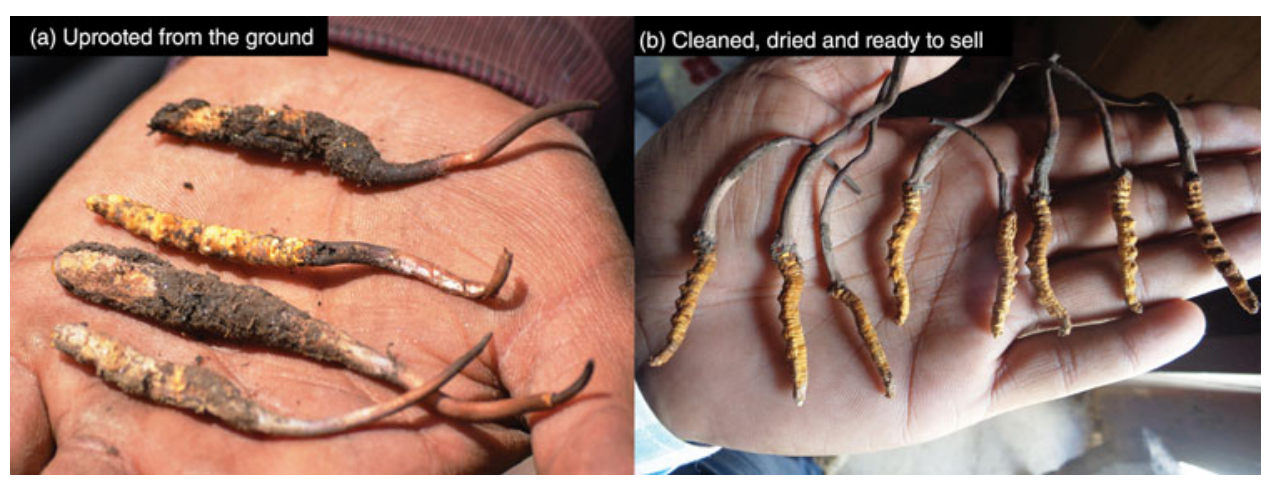

Plate 1 Caterpillar fungus Ophiocordyceps sinensis (a) uprooted from the ground, and (b) cleaned, dried and ready to sell.

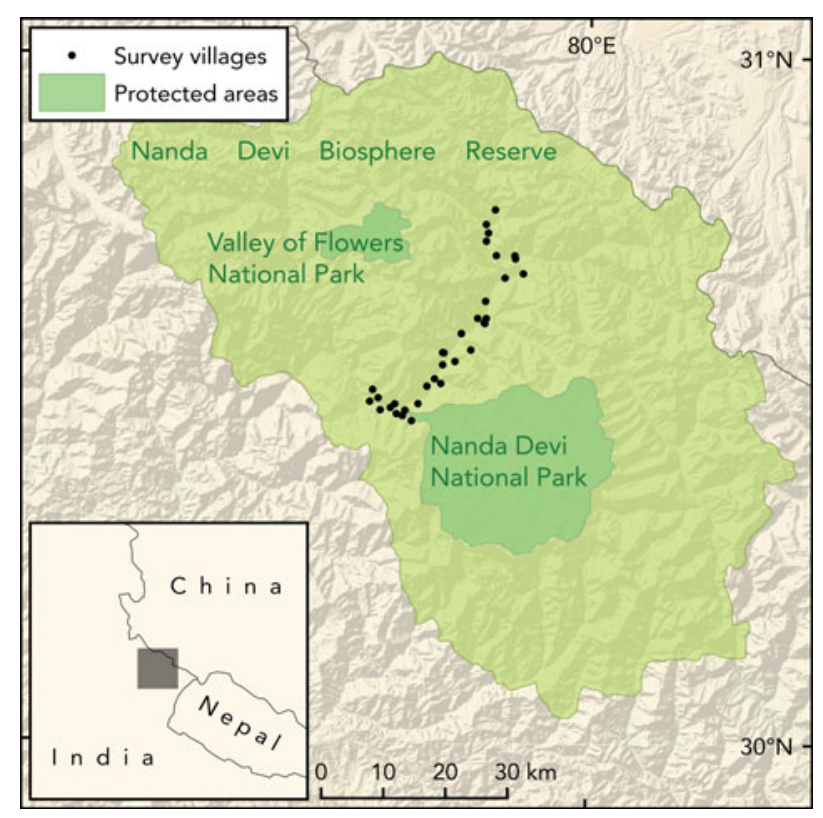

FIG. 1 Location of the study villages in Nanda Devi Biosphere Reserve, Uttarakhand, India.

Nanda Devi National Park and Valley of Flowers National Park, are free from human settlements and are home to many threatened species. The buffer zone is inhabited predominantly by people of the Bhotiya tribe, a community of Indo-Tibetan people who have historically earned their livelihoods as shepherds, porters and traders. The traditional cottage industries in this region, including weaving on handlooms, livestock rearing and production of a local alcoholic beverage, provide subsistence livelihoods to the inhabitants. Ecotourism is another vital source of income, with more than 1 million pilgrims and tourists visiting religious shrines (Badrinath and Hemkund Sahib) and the Valley of Flowers National Park each year.

Since the Biosphere Reserve was established, there have been conflicts between the protected area authority and local people (Maikhuri et al., 2001), and there have been several boom-and-bust cycles in the local economy. The Niti Pass, within the Biosphere Reserve, which was an ancient silk route for trans-border trade between Tibet and the lowlands of India, was closed after the Indo-China war in 1962, leading to socio-economic transformation in the region (Silori, 2007). Local livelihoods shifted to pastoralism, the collection of NTFPs, and generating income from tourism activities such as mountaineering. After the area was officially declared a National Park in 1982, all human activities were halted, including mountaineering, herding and collection of NTFPs in the core zone, which resulted in the loss of sources of income (Rao et al., 2000; Bhattacharya \& Sathyakumar, 2011). The local people perceive the closure of the core zone to have affected their material wealth and to have caused unwanted changes in their livelihood strategies. As a result, many people from the Bhotiya tribe opposed enforcement of the Biosphere Reserve and actively resisted and contested such policies (Kent et al., 2012). Several protests and movements were organized to demand the restoration of traditional rights to use resources within the Reserve. In 1998, the most significant movement, called jhapto-cheeno (swoop and grab), saw an estimated 600 people peacefully enter the core zone of the Biosphere Reserve (Nanda Devi National Park), pick flowers, and voice their desire for the restoration of their traditional rights to use the natural resources of the area (Kent et al., 2012).

To address grievances, in 1992 the government allowed local people to collect medicinal plants for their personal use but not for sale (Maikhuri et al., 2001). Likewise, in 2003 the core zone of the Biosphere Reserve was opened to regulated tourism, with entry fees, restrictions on tourist numbers (c. 500 tourists per year), and employing only local people as porters and tourist guides (Saxena et al., 2011). The implications of conservation initiatives and policies for management of natural resources (including caterpillar fungus) and the traditional rights of the local communities in the Reserve have been extensively debated (Maikhuri et al., 2001; Silori, 2007; Bosak, 2008; Bhattacharya \& Sathyakumar, 2011; Saxena et al., 2011).

\section{Methods}

\section{Data collection and analysis}

We collected data through interviews, group discussions, and formal and informal communication with village leaders, 
school teachers and government officials. Key informants from the forest department and village councils helped us identify 32 villages within the Biosphere Reserve's Dhauliganga Valley, whose inhabitants are involved in the harvest and trade of the caterpillar fungus. We conducted the survey during May 2015-July 2016 after obtaining permission from the Uttarakhand Forest Department. Before starting the survey, the questionnaire was tested among 12 harvesters and modified to rectify ambiguities.

We collected the names of the household heads of each village and identified those households that fulfilled two criteria: (1) they had been involved in the harvesting of caterpillar fungus for at least 5 years, and (2) they had spent a minimum of 10 days collecting the fungus during the previous harvesting season. We selected households based on these criteria so that interviewees would have experience in and an understanding of the dynamics of caterpillar fungus harvesting and trade. We also hoped they would be able to remember the amount of fungus harvested, or their earnings from the caterpillar fungus, in the previous 5 years. Interviewees were selected randomly from the lists of household heads. If the selected person was unavailable or declined to be interviewed, a substitute was selected randomly from the lists. A single household was considered a unit for measuring economic parameters. Interviews were conducted with the head of the household or the person involved in decision-making. We collected data from 312 households (c. 10\% of the total number of households). We also conducted informal meetings and discussions with 11 village council leaders, three school teachers, and seven forest department officials, to triangulate information gathered from the key informant interviews. Additionally, 24 local traders were interviewed to collect market information. Before starting the interviews, we received verbal consent from the respondents, who were informed they were under no obligation to answer questions. Anonymity and confidentiality of the respondents' personal information were guaranteed.

The structured survey questionnaire comprised three major parts: questions related to demographic features of households, including the respondents' age, gender and education, and the source of household cash income; questions about the amount of harvest, days spent in the pasture, and selling price; questions about the harvester's perception of the abundance of the resource, and problems and challenges of harvesting of caterpillar fungus. Respondents were able to recall their annual earnings, as the collection of caterpillar fungus in this area has become a major source of cash income. For income accounting, we focused only on cash income earned by the household in the survey year, as our goal was to quantify the relative contribution of the fungus harvesting to household cash income. Statistical analyses were carried out with $R$ 3.3.1 (R Development Core Team, 2016). The demographic
TABLE 1 Demographic characteristics of the 312 survey respondents in Nanda Devi Biosphere Reserve, Uttarakhand, India (Fig. 1).

\begin{tabular}{ll}
\hline Demographic characteristics & $\begin{array}{l}\text { Number (\%) / } \\
\text { Mean } \pm \text { SD }\end{array}$ \\
\hline Gender & $204(65.4)$ \\
$\quad$ Male & $108(34.6)$ \\
Female & \\
Origin & $312(100)$ \\
$\quad$ Native of the reserve & 0 \\
$\quad$ Non-native of the reserve & $35.5 \pm 8.5$ \\
Age (years) & $7.1 \pm 1.5$ \\
Caterpillar fungus harvesting experience (years) & $8.1 \pm 2.6$ \\
Mean family size & $5.3 \pm 2.3$ \\
Mean no. of family members involved in & \\
$\quad$ harvesting & $36.4 \pm 4.8$ \\
Mean time spent harvesting in 2015 (days) & \\
Level of education & $42(13.5)$ \\
$\quad$ Illiterate & $61(19.6)$ \\
Literate & $149(47.8)$ \\
Secondary school & $60(19.2)$ \\
$\quad$ Bachelors degree or higher &
\end{tabular}

characteristics of the respondents are summarized in Table 1. We constructed the range of annual buying and selling prices of the fungus and used linear regression to ascertain any trends in buying and selling prices during 2006-2015. The buying price is the price at which local traders buy from the harvesters in villages, and the selling price is the price for which local traders sell the fungus to wholesalers beyond the villages.

\section{Results}

\section{Market trend of caterpillar fungus}

The market for caterpillar fungus has changed considerably over time, with significant variation in both buying and selling prices (Fig. 2). The mean annual buying price for local traders in villages increased from USD 4,784 \pm SD 730 per $\mathrm{kg}$ in 2006 to USD 16,930 \pm SD 2,606 per kg in 2013 and then declined in 2014 (USD 15,562 \pm SD 2,844) per kg and 2015 (USD 13,052 \pm SD 1,670) per kg (Fig. 2a). However, compared to the price in 2006, the mean buying price in 2015 was c. three times higher. During this period, the mean annual increase in buying price was USD 1,097 \pm SE 26 per year $(\mathrm{P}<0.001)$. Likewise, the mean annual selling price of caterpillar fungus for local traders increased from USD 6,677 \pm SD 1,014 per kg in 2006 to USD 25,039 \pm SD 2,226 per kg in 2013, decreased in 2014 (USD 23,337 \pm SD 2,595), and then increased again to a high of USD 25,334 \pm SD 2,284 per kg in 2015 (Fig. 2b). Thus, the mean annual increase in selling price from local traders to wholesalers was USD 2,100 \pm SE 8 o per year $(\mathrm{P}<0.001)$. 


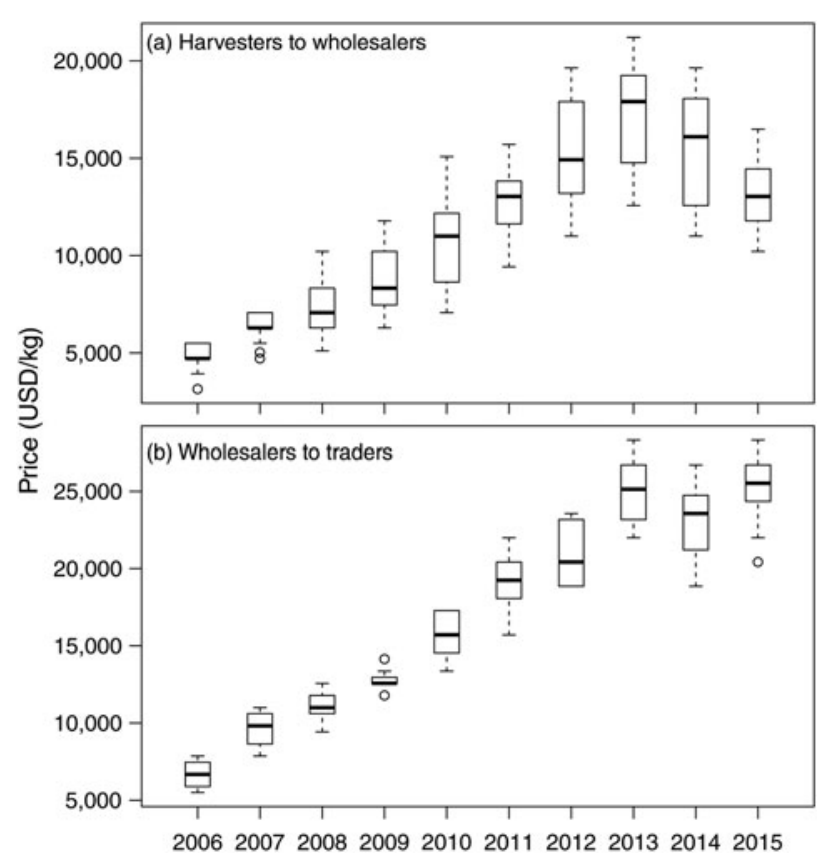

FIG. 2 Trends in selling price (as boxplots, with mid line of box indicating median) of caterpillar fungus Ophiocordyceps sinensis from Nanda Devi Biosphere Reserve (Fig. 1), (a) from harvesters to wholesalers and (b) from wholesalers to tradersduring 20062015. Note the differing $y$-axis scales.

\section{Contribution of caterpillar fungus to household cash income}

The cash income from harvesting of caterpillar fungus increased the total household cash income of harvesters in the Biosphere Reserve, giving them the means to buy food, pay for health care and education, and run small businesses. The proportional contribution of cash income from fungus harvesting was c. $74.2 \%$ of a household's total cash income (Fig. 3). It has surpassed traditional sources of income, such as collection of other forest products, seasonal labour, farming and livestock. The trends in household cash income from caterpillar fungus indicate a steady rise between 2011 (USD 1,294 \pm SD 335) and 2013 (USD 2,211 \pm SD 427), followed by a downwards trend in 2014 and 2015 (Fig. 4). The mean annual increase in household cash income from caterpillar fungus was USD $50 \pm$ SE $8(\mathrm{P}<0.001)$.

\section{Harvesters' perceptions of harvesting}

More than three quarters $(78.2 \%)$ of the harvesters felt that harvesting has become more difficult as a result of competition and reduced abundance of the species (Fig. 5a), and $82.5 \%$ of harvesters perceived that the fungus has become less abundant (Fig. 5b). This experience of harvesters was supported by the decrease in per capita harvest during 2011-2015, which declined by a mean of $54 \pm \mathrm{SE} 2$ pieces

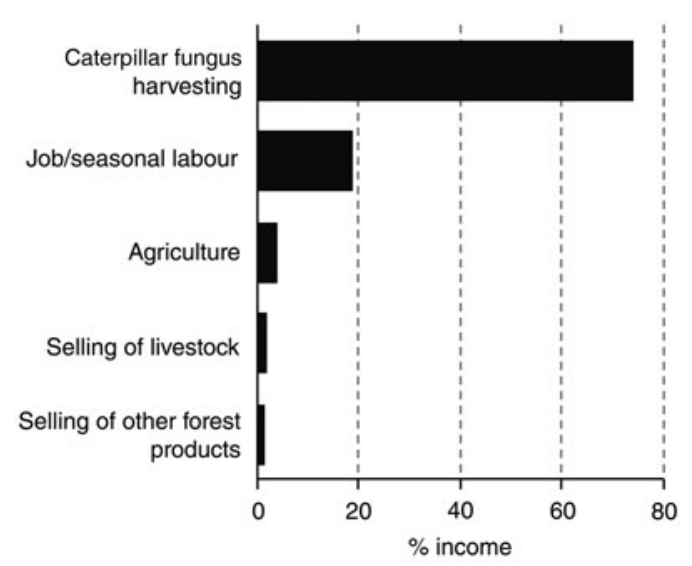

Fig. 3 Sources of cash income for harvesters of caterpillar fungus in Nanda Devi Biosphere Reserve (Fig. 1), with \% contribution to total income in 2015 .

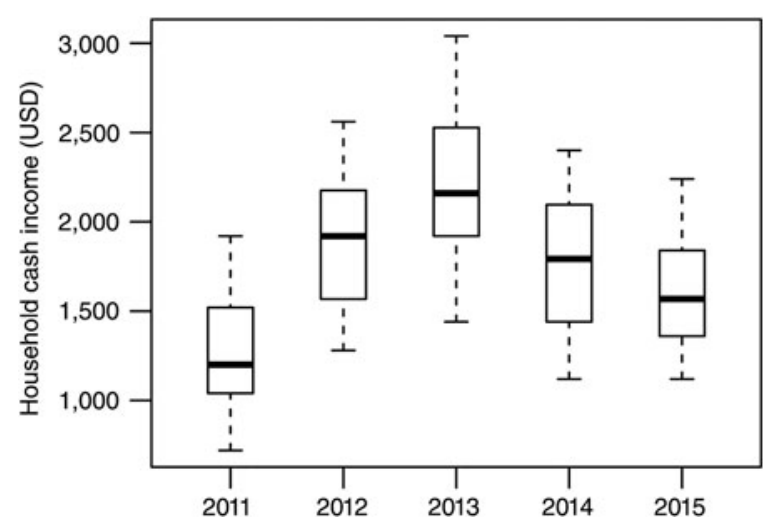

Fig. 4 Household income (as boxplots, with mid line of box indicating median) from caterpillar fungus in study villages in Nanda Devi Biosphere Reserve (Fig. 1) during 2011-2015.

per year $(\mathrm{P}<0.001)$ during the study period (Fig. 6). In 2015 harvesters spent more days collecting compared to 2011; the mean number of days increased by $2.2 \pm \mathrm{SE} 0.08$ days per year $(\mathrm{P}<0.001)$ during 2011-2015.

School teachers, village council leaders and forest department officials also appeared to be concerned about decreasing production of the fungus and a concomitant increase in disputes and conflicts between the local authority (the forest department) and fungus harvesters and traders. Our discussions with harvesters, traders and local authorities indicated that community disputes in the past generally occurred over grazing rights, but the major focus of recent conflict was access to the areas where caterpillar fungus can be collected. Most (79.5\%) harvesters indicated that legal issues related to harvesting and trade of caterpillar fungus are one of the biggest challenges, followed by the dangerous terrain and unpredictable weather in the pastures (12.5\%; Fig. 7). Collectors often suffer snow blindness, altitudinal sickness and joint pain, and may have problems with breathing 

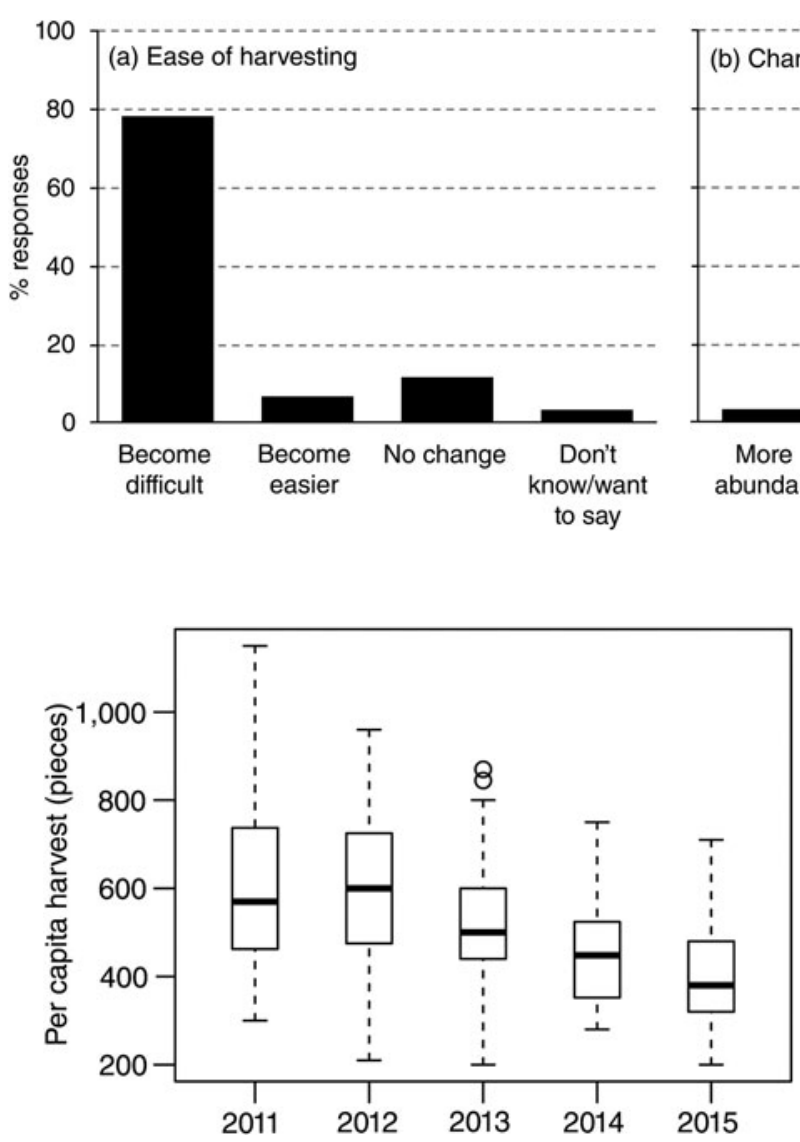

FIG. 6 Annual per capita harvest of caterpillar fungus in Nanda Devi Biosphere Reserve during 2011-2015.

and sleeping as a result of weeks of hardship in the highaltitude alpine meadows. The conditions (e.g. temporary camping and poor food) during the harvesting period are difficult, and harvesters fear attacks by wildlife.

\section{Discussion}

Our study is one of the first comprehensive efforts to analyse trends in the harvesting and trade of caterpillar fungus in India. It documents harvesters' perceptions of challenges regarding the harvesting of the fungus, and quantifies its contribution to the household cash income of the local communities. Our findings indicate that harvesting of the caterpillar fungus had become an important livelihood option for the mountain communities in the Nanda Devi Biosphere Reserve within a decade of its discovery there, despite ambiguity regarding the legality of the collection and trade of the fungus. The price of caterpillar fungus has increased considerably, and it has become the major source of income for local households. People in this landscape are extensively involved in collecting and trading of the fungus during May-July every year.

The increase in market prices of caterpillar fungus recorded here corresponds with the price increase in

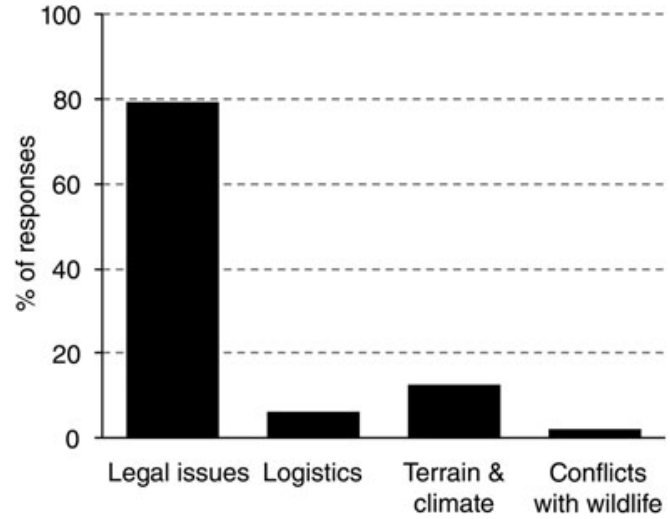

FIG. 7 Harvesters' perceptions of the problems and challenges of harvesting caterpillar fungus in Nanda Devi Biosphere Reserve (Fig. 1).

neighbouring Tibet (Winkler, 2010) and Nepal (Shrestha \& Bawa, 2013). Despite the recent decline in selling prices for harvesters and local traders, average selling prices have generally remained high. The market price of the fungus is unpredictable and large fluctuations are common. Price is influenced by many factors, including market demand, the timing of the sale, the involvement of middlemen, the quality and origin of the fungus (in some localities the fungus is larger and thus commands a higher price), and the trading location (Shrestha \& Bawa, 2014). The monopoly of local traders in villages also determines the price. In 2015 a decrease in the price of the fungus was also reported in Nepal (Badu, 2015), and therefore the decline in price in our study area may be attributable to a decline in the international market.

Despite the hardships and risks involved in collecting caterpillar fungus, and recent fluctuations in price, collection of the fungus remains lucrative, as the economic costs involved are low, there are few employment options available locally, agricultural productivity is minimal, and other livelihood options in the region are limited. The fungus is a vital natural resource for generating cash income and is an important economic commodity. Our findings regarding the economic contribution of the fungus to 
household cash income are comparable to those of studies conducted in other regions of the Himalaya $(64.5 \%$ in Jumla, Nepal, Shrestha et al., 2017; 53.3\% in Dolpa, Nepal, Shrestha \& Bawa, 2014; 72\% in Sangdui Valley, China, Woodhouse et al., 2014; 98\% in Chamoli, India, Kuniyal \& Sundriyal, 2013; and 80-100\% in Bhutan, Wangchuk et al., 2012). Given its reliance on the species for cash earnings, a decline in harvest rate or in price could be catastrophic for the local community. As many harvesters pointed out, the legal ambiguity remained a challenge for caterpillar fungus harvesting and trade. In many parts of India the collection of the fungus is legal but trade is illegal (Jeffrey \& Dyson, 2012). This has led to smuggling of caterpillar fungus into Nepal and China, and selling on the black market. For instance, collectors or local traders from the Indian Himalaya sell their harvest of caterpillar fungus to Nepalese traders passing across the open Indo-Nepal border (Pant et al., 2017; Press Trust of India, 2017).

To address the problems associated with this illegal yet substantial trade, the State Government of Uttarakhand has issued guidelines for the collection and trade of the caterpillar fungus from reserve forests (commercial exploitation from wildlife sanctuaries and national parks is completely prohibited) through village-level forest councils called Van Panchayat. According to the guidelines, based on the 1927 Indian Forest Act, the Van Panchayat issues permits for collection of the fungus, and each collector has to pay a royalty of INR 1,000 (USD 15.7) per $100 \mathrm{~g}$ of the fungus. The forest department buys the produce by paying INR 50,000 (USD 786) per kg as advance money to the harvester, and later auctions the collection to traders authorized by trading permits. The balance after the auction is paid to the harvester after deducting a 10\% commission.

However, in reality, sites where collection is prohibited (national parks and sanctuaries) remain open for caterpillar fungus harvesting, as the government rules are not strictly enforced and often the collection sites are in remote locations (Negi et al., 2015). Local people try to conceal this reality, and during our survey they were reluctant to be interviewed about the amount of harvesting and trade, as they were doubtful about our intentions. After several rounds of conversations with village heads, meetings with the representatives of village councils, and organizing outreach programmes in schools, we built trust and overcame this reticence. Given the low profits in the formal authorized trade and the lack of appropriate institutional mechanisms for monitoring, harvesters and local traders around the Biosphere Reserve are mostly involved in illegal trade, for large profits. The local administration and forest department occasionally become involved in detaining harvesters and traders (Moudgil, 2017; Sharma, 2017; Press Trust of India, 2017) but the trade continues unabated as ambiguities and complexities remain in the regulations, and there is no single government policy regarding the collection and trade of the fungus.

Despite the risks and challenges, thousands of people are involved in the harvesting and trade of the caterpillar fungus in the study landscape. The majority of the harvesters believed that abundance of the fungus has decreased, and this is supported by our data on per capita harvest. A similar decline has been reported elsewhere (Shrestha \& Bawa, 2013; Shrestha et al., 2017). However, the decline could alternatively be attributed to the increase in the number of collectors: the mean number of family members involved in collecting increased slightly from $3.3 \pm$ SD 1.3 members per family in 2011 to $4.5 \pm$ SD 1.7 in 2015 . Nevertheless, the reduced abundance has raised concerns regarding the sustainability of the harvest in Bhutan (Cannon et al., 2009) and Nepal (Shrestha \& Bawa, 2013). Shrestha \& Bawa (2013) attributed the reported decline to overharvesting, premature harvesting, a decrease in moth and larval populations, unintentional modification by the harvesters of the soil microhabitats congenial to fungal spores, increased grazing intensity, or climate change.

As reported elsewhere (Shrestha \& Bawa, 2013), harvesters in the study area picked every caterpillar fungus they encountered, leaving only those individuals that were not visible. With thousands of harvesters collecting the fungus, there were few remaining for reproduction by the end of the harvesting season. This intense and destructive harvesting practice may have adversely affected the population of the fungus; however, robust evidence of the impacts of harvesting on populations of the caterpillar fungus is still lacking. We observed soil compaction, destruction of alpine flora by trampling, and deposition of waste such as plastics, paper and human faeces by the harvesters in the alpine pastures. Banning collection and restricting access to the alpine meadows would affect the income of the mountain dwellers, and therefore sustainable management is necessary to ensure minimal ecological impact on the species and its habitat while enhancing household economies.

Caterpillar fungus harvesting in the Biosphere Reserve presents various challenges related to the environment, legal processes and local livelihoods. To manage the fungus sustainably, government policies need to be formulated and implemented, integrating aspects of biodiversity conservation, livelihood security and good governance. Holistic management of the fungus would be favourable from a conservation perspective as well as for the economic well-being of the Indigenous communities. There is also a need to explore supplementary livelihood opportunities, such as jobs in the tourism sector, up-scaling of local handloom enterprises, livestock husbandry, and sustainable collection of other NTFP species, to incentivize harvesters to reduce their dependence on the caterpillar fungus. We observed that harvesters were not aware of the life history of the caterpillar fungus or the adverse impact of harvesting, including soil 
compaction, and therefore we also recommend extensive outreach and capacity-building programmes to promote sustainable harvesting and minimization of ecological damage (e.g. management of plastic waste) during harvesting.

Acknowledgements We thank the Conservation Leadership Programme (Future Conservationist Award 2015), Idea Wild and the Rufford Small Grants Foundation for funding this research, the Uttarakhand Forest Department for granting necessary permissions to work in the Nanda Devi Biosphere Reserve and providing regulatory documents on caterpillar fungus harvesting, the officials and communities of the Biosphere Reserve for their generosity and hospitality during the field surveys, and the mentoring provided by a Writing for Conservation Workshop organized by Fauna \& Flora International and the Conservation Leadership Programme.

Author contributions Design and analysis: UBS and PKY; writing and revision: all authors; data collection: all authors except UBS.

\section{Conflicts of interest None.}

Ethical standards This research project was approved by Centre for Integration of Conservation and Developmental Accountability, India.

\section{References}

Angelsen, A., Jagger, P., Babigumira, R., Belcher, B., Hogarth, N.J., BAUCH, S. et al. (2014) Environmental income and rural livelihoods: a global-comparative analysis. World Development, 64, S12-S28.

BADU, M. (2015) Yarsagumba collectors unhappy as prices plunge. The Kathmandu Post. Http://kathmandupost.ekantipur.com/ printedition/news/2015-08-12/yarsagumba-collectors-unhappyas-prices-plunge.html [accessed 13 August 2015].

Bhattacharya, T. \& Sathyakumar, S. (2011) Natural resource use by humans and response of wild ungulates. Mountain Research and Development, 31, 209-219.

Bosa K, K. (2008) Nature, conflict and biodiversity conservation in the Nanda Devi Biosphere Reserve. Conservation and Society, 6, 211-224.

Bosak, K. \& Kainthola, S. (2016) Going global: livelihoods and globalization in the Niti Valley, Garhwal Himalaya, India. In Globalization and Marginalization in Mountain Regions (eds R. Chand \& W. Leimgruber), pp. 121-134. Springer, Cham, Switzerland.

Cannon, P.F., Hywel-Jones, N.L., Maczey, N., Norbu, L., Tshitila, Samdup, T. \& Lhendup, P. (2009) Steps towards sustainable harvest of Ophiocordyceps sinensis in Bhutan. Biodiversity and Conservation, 18, 2263-2281.

Dash, M., Behera, B. \& Rahut, D.B. (2016) Determinants of household collection of non-timber forest products (NTFPs) and alternative livelihood activities in Similipal Tiger Reserve, India. Forest Policy and Economics, 73, 215-228.

DonG, C.H. \& YAO, Y.J. (2008) In vitro evaluation of antioxidant activities of aqueous extracts from natural and cultured mycelia of Cordyceps sinensis. LWT - Food Science and Technology, 41, 669-677.

Garbyal, S.S., AgGarwal, K.K. \& Babu, C.R. (2004) Impact of Cordyceps sinensis in the rural economy of interior villages of Dharchula sub-division of Kumaon Himalayas and its implications in the society. Indian Journal of Traditional Knowledge, 3, 182-186.

Holliday, J.C. \& Cleaver, M. (2008) Medicinal value of the caterpillar fungi species of the genus Cordyceps (Fr.) Link
(Ascomycetes). A review. International Journal of Medicinal Mushrooms, 10, 219-234.

Jeffrey, C. \& Dyson, J. (2012) India banks on rush for aphrodisiac fungus before supply droops. The Guardian. Https://www. theguardian.com/global-development/2012/jul/30/ india-aphrodisiac-fungus-supply-droops [accessed 20 July 2016].

Ji, D.B., Ye, J., Li, C.L., WANG, Y.H., ZhaO, J. \& CAI, S.Q. (2009) Antiaging effect of Cordyceps sinensis extract. Phytotherapy Research, 23, 116-122.

Kent, K., Sinclair, A.J. \& Diduck, A. (2012) Stakeholder engagement in sustainable adventure tourism development in the Nanda Devi Biosphere Reserve, India. International Journal of Sustainable Development \& World Ecology, 19, 89-100.

KuniYal, C.P. \& Sundriyal, R.C. (2013) Conservation salvage of Cordyceps sinensis collection in the Himalayan mountains is neglected. Ecosystem Services, 3, 40-43.

Mahapatra, A.K. \& Shackleton, C.M. (2011) Has deregulation of non-timber forest product controls and marketing in Orissa state (India) affected local patterns of use and marketing. Forest Policy and Economics, 13, 622-629.

Maikhuri, R.K., Nautiyal, S., Rao, K.S. \& Saxena, K.G. (2001) Conservation policy-people conflicts: a case study from Nanda Devi Biosphere Reserve (a World Heritage Site), India. Forest Policy and Economics, 2, 355-365.

Moudgil, A. (2017) Chamoli emerging as 'Yarsagumba' smuggling hub. The Hindustan Times. Dehradun, India.

Negi, C.S., Pant, M., Joshi, P. \& Bohra, S. (2014) Yar tsa Gunbu [Ophiocordyceps sinensis (Berk.) G.H. Sung et al.]: the issue of its sustainability. Current Science, 107, 882-887.

Negi, C.S., Joshi, P. \& Bohra, S. (2015) Rapid vulnerability assessment of Yartsa Gunbu (Ophiocordyceps sinensis [Berk.] G.H. Sung et al.) in Pithoragarh District, Uttarakhand State, India. Mountain Research and Development, 35, 382-391.

Pant, B., Rai, R.K., Wallrapp, C., Ghate, R., Shrestha, U.B. \& RAm, A. (2017) Horizontal integration of multiple institutions: solutions for Yarshagumba related conflict in the Himalayan region of Nepal? International Journal of the Commons, 11, 464-486.

Press Trust of India (2017) Two Indians arrested for carrying Himalayan herb Yarsagumba. India Today. Http://indiatoday. intoday.in/story/two-indians-arrested-for-carrying-himalayanherb-yarsagumba/1/1045739.html [accessed 12 September 2017].

R Development Core Team (2016) R: A Language and Environment for Statistical Computing. R Foundation for Statistical Computing, Vienna, Austria.

Rao, K.S., Nautiyal, S., Maikhuri, R.K. \& Saxena, K.G. (2000) Management conflicts in the Nanda Devi Biosphere Reserve, India. Mountain Research and Development, 20, 320-323.

Rijal, A., Smith-Hall, C. \& Helles, F. (2011) Non-timber forest product dependency in the Central Himalayan foot hills. Environment, Development and Sustainability, 13, 121-140.

SAXena, K.G., MaikhURI, R.K. \& RaO, K.S. (2011) Ecotourism in Nanda Devi Biosphere Reserve: a win-win option for environmental conservation and sustainable livelihoods. Biosphere Reserves in the Mountains of the World, 77-80.

Secretariat of the Convention on Biological Diversity (SCBD) (2001) Sustainable Management of Non-timber Forest Resources. CBD Technical Series no. 6. SCBD, Montreal, Canada.

Sharma, N. (2017) Uttarakhand may adopt Bhutan model to regulate Himalayan Viagra extraction and trade. The Hindustan Times. Dehradun, India.

Sharma, S. (2004) Trade of Cordyceps sinensis from high altitudes of the Indian Himalaya: conservation and biotechnological priorities. Current Science, 86, 1614-1619. 
Shrestha, B., Zhang, W., Zhang, Y. \& LiU, X. (2010) What is the Chinese caterpillar fungus Ophiocordyceps sinensis (Ophiocordycipitaceae)? Mycology, 1, 228-236.

Shrestha, U.B. \& BAWA, K.S. (2013) Trade, harvest, and conservation of caterpillar fungus (Ophiocordyceps sinensis) in the Himalayas. Biological Conservation, 159, 514-520.

Shrestha, U.B. \& BAWA, K.S. (2014) Economic contribution of Chinese caterpillar fungus to the livelihoods of mountain communities in Nepal. Biological Conservation, 177, 194-202.

Shrestha, U.B., Dhital, K.R. \& Gautam, A.P. (2017) Economic dependence of mountain communities on Chinese caterpillar fungus Ophiocordyceps sinensis (yarsagumba): a case from western Nepal. Oryx, published online 26 July 2017.

SiLORI, C.S. (2007) Perception of local people towards conservation of forest resources in Nanda Devi Biosphere Reserve, north-western Himalaya, India. Biodiversity and Conservation, 16, 211-222.

Singh, N., Pathak, R., Kathait, A.S., Rautela, D. \& Dubey, A. (2010) Collection of Cordyceps sinensis (Berk.) Sacc. in the interior villages of Chamoli district in Garhwal Himalaya (Uttarakhand) and its social impacts. Journal of American Science, 6, 120-132.

Smith, O.C. \& Larsen, H.O. (2003) Alpine medicinal plant trade and Himalayan mountain livelihood strategies. The Geographical Journal, 169, 243-254.

Tewari, J.C., Pareek, K., Shiran, K. \& Roy, M.M. (2017) Non timber tree products: alternative source of livelihood in man-crop/grasslivestock-tree/shrub continuum of arid regions. MOJ Ecology \& Environmental Science, 2, 1-7.

WANG, X.L. \& YAO, Y.J. (2011) Host insect species of Ophiocordyceps sinensis: a review. Zoo Keys, 127, 43-59.
Wangchuk, S., Norbu, N. \& Sherub (2012) Impacts of Cordyceps Collection on Livelihoods and Alpine Ecosystems in Bhutan as Ascertained from Questionnaire Survey of Cordyceps Collectors. Royal Government of Bhutan, UWICE Press, Bumthang, Bhutan.

Weckerle, C.S., Yang, Y., Huber, F.K. \& Li, Q. (2010) People, money, and protected areas: the collection of the caterpillar mushroom Ophiocordyceps sinensis in the Baima Xueshan Nature Reserve, Southwest China. Biodiversity and Conservation, 19, 2685-2698.

Winkler, D. (2009) Caterpillar fungus (Ophiocordyceps sinensis) production and sustainability on the Tibetan Plateau and in the Himalayas. Asian Medicine, 5, 291-316.

Woodhouse, E., McGowan, P. \& Milner-Gulland, E.J. (2014) Fungal gold and firewood on the Tibetan plateau: examining access to diverse ecosystem provisioning services within a rural community. Oryx, 48, 30-38.

Yadav, P.K., Saha, S., Mishra, A.K., Kapoor, M., Kaneria, M. \& KAneria, M. (2016) Conserving Ophiocordyceps sinensis in the Nanda Devi Biosphere Reserve, India, Technical report. Dehradun, India.

Yadav, P.K., Mishra, A.K., Kaneria, M., Kapoor, M., Kaneria, M. \& Aziem, S. (2017) Caterpillar fungus gold rush: growing dependence on a lucrative trade with disputes among communities in the Himalaya. Climate Change and Environmental Sustainability, 5, 92-96.

Yalin, W., Ishurd, O., Cuirong, S. \& Yuanjiang, P. (2005) Structure analysis and antitumor activity of $(1 \rightarrow 3)$ - $\beta$-D-glucans (cordyglucans) from the mycelia of Cordyceps sinensis. Planta Medica, 71, 381-384. 